\title{
Physical activity, fat intake and body fat
}

\author{
Citation for published version (APA):
}

Goris, A. H., \& Westerterp, K. R. (2008). Physical activity, fat intake and body fat. Physiology \& Behavior, 94(2), 164-168. https://doi.org/10.1016/j.physbeh.2007.11.009

Document status and date:

Published: 01/01/2008

DOI:

10.1016/j.physbeh.2007.11.009

Document Version:

Publisher's PDF, also known as Version of record

\section{Document license:}

Taverne

\section{Please check the document version of this publication:}

- A submitted manuscript is the version of the article upon submission and before peer-review. There can be important differences between the submitted version and the official published version of record.

People interested in the research are advised to contact the author for the final version of the publication, or visit the DOI to the publisher's website.

- The final author version and the galley proof are versions of the publication after peer review.

- The final published version features the final layout of the paper including the volume, issue and page numbers.

Link to publication

\footnotetext{
General rights rights.

- You may freely distribute the URL identifying the publication in the public portal. please follow below link for the End User Agreement:

www.umlib.nl/taverne-license

Take down policy

If you believe that this document breaches copyright please contact us at:

repository@maastrichtuniversity.nl

providing details and we will investigate your claim.
}

Copyright and moral rights for the publications made accessible in the public portal are retained by the authors and/or other copyright owners and it is a condition of accessing publications that users recognise and abide by the legal requirements associated with these

- Users may download and print one copy of any publication from the public portal for the purpose of private study or research.

- You may not further distribute the material or use it for any profit-making activity or commercial gain

If the publication is distributed under the terms of Article $25 \mathrm{fa}$ of the Dutch Copyright Act, indicated by the "Taverne" license above, 


\title{
Physical activity, fat intake and body fat
}

\author{
Annelies H.C. Goris ${ }^{\text {a }}$, Klaas R. Westerterp ${ }^{\text {b,* }}$ \\ ${ }^{\text {a }}$ Care and Health Applications, Philips Research, Eindhoven, The Netherlands \\ ${ }^{\mathrm{b}}$ Department of Human Biology, Maastricht University, Maastricht, The Netherlands
}

Received 20 August 2007; received in revised form 5 November 2007; accepted 7 November 2007

\begin{abstract}
The body fatness of a subject is a long-term reflection of the energy balance, the more intake exceeds expenditure the more energy is stored as fat. There is not yet a clear answer on the question whether the current obesity epidemic is a consequence of gluttony or sloth. Review studies do not show a reduction of physical activity over the years, and food intake is difficult to measure in daily life conditions. Food intake can only be derived from self-report, where under-reporting of food intake and selective underreporting of fat intake are major issues. Fat intake might be an important factor in the increase of body weight. Many studies suggest the capacity of the body to oxidize dietary fat is a major risk factor for a positive energy balance. Additionally, there is evidence that most of the fat consumed is stored before oxidation. Obesity prone subjects might be characterized by a higher storage of dietary fat. The only way to increase the oxidation of dietary fat, other than consuming more dietary fat, is to increase energy expenditure by an increase of physical activity. Indeed, there are indications that physical activity is an important determinant of fat oxidation. Based on the evidence presented, it is concluded that the obesity epidemic is mainly due to a high dietary intake, especially as fat, and that physical activity can be a tool to modulate the effect of fat intake on body fat.
\end{abstract}

(C) 2007 Elsevier Inc. All rights reserved.

Keywords: Physical activity level; doubly labeled water; underreporting; adaptive thermogenesis; overweight

\section{Introduction}

The prevalence of obesity increases rapidly worldwide, with Middle East, Central and Eastern Europe and North America having the highest prevalence rates [1]. Wang et al. calculated an annual increase in prevalence ranging from 0.3 to $0.9 \%$ points across the different populations within the USA. By 2015 this will mean that $75 \%$ of adults will be overweight or obese [2]. Increasing body mass has several health related side effects. Willet et al found a linear relation between body mass index and diabetes, hypertension, gallstones, and coronary heart disease with a BMI nadir of about 19 or $20 \mathrm{~kg} / \mathrm{m}^{2}$ [3]. Worldwide a high BMI puts a $2.3 \%$ on total burden of global disease [4].

The obesity epidemic could be due to increased food intake, reduced activity or a combination of both. Is the obesity epide-

\footnotetext{
* Corresponding author. Department of Human Biology, Maastricht University, PO Box 616, 6200 MD Maastricht, The Netherlands. Tel.: +31 43 3881628; fax: +31 433670976 .

E-mail address: K.Westerterp@HB.Unimaas.NL (K.R. Westerterp).
}

mic a consequence of gluttony or sloth? Besides total food intake dietary fat intake might have an additional effect on body weight. This review summarizes findings of laboratory studies and field trials including measurement of physical activity, dietary energy and fat intake and the effect on body fat. Once the relations between dietary energy, fat intake and physical activity are clear intervention strategies for successful prevention of weight gain, weight loss or weight loss maintenance can be formulated.

\subsection{Physical activity}

Physical activity can be defined by several terms, including activity energy expenditure (AEE) per kg body mass, physical activity level (PAL, daily energy expenditure as a multiple of resting energy expenditure), time spent in activities etc. The validity of all these physical activity measures depends on the method used to assess physical activity and on the targeted population. For instance, PAL can be used for adults to describe physical activity, but is less suitable to describe physical activity in children. For this group AEE/kg body mass is a better choice 
Table 1

Mean physical activity level, doubly labeled water assessed total daily energy expenditure as a multiple of resting energy expenditure, by gender and age group [7]

\begin{tabular}{lll}
\hline Age $(\mathrm{y})$ & men $(\mathrm{n}=169)$ & women $(\mathrm{n}=238)$ \\
\hline $19-30$ & 1.74 & 1.80 \\
$31-50$ & 1.81 & 1.83 \\
$51-70$ & 1.63 & 1.70 \\
$>70$ & 1.52 & 1.33 \\
\hline
\end{tabular}

to describe physical activity $[5,6]$. In this paragraph recent studies are reviewed which measured physical activity, using different terms and methods, in healthy adult populations.

The golden standard for the measurement of total daily energy expenditure under free-living conditions is the doubly labeled water method. This is a rather expensive method and therefore not suitable to get information on PAL and AEE for large epidemiological studies. Combination of doubly labeled water studies gives, however, an overview of physical activity in healthy adult populations. Brooks et al reviewed 407 doubly labeled water measurements in healthy, normal weight adults within the age category 19-50 years of age and found that the mean PAL was above 1.7 (Table 1) [7]. Data from studies involving very active people (like military people, elite athletes) were excluded. A PAL of 1.7 is in agreement with international recommendations [8]. Blair et al. [9] analyzed the same database of doubly labeled water measurements as Brooks et al. and did find no differences in PAL between normal weight and overweight or obese people, except for women between 5170 years of age (Table 2). Comparable results were found by Butte et al who measured energy expenditure also with the doubly labeled water method in 116 women between 1840 years with low body mass index $\left(\mathrm{BMI},<18.5 \mathrm{~kg} / \mathrm{m}^{2}\right)$, normal BMI $\left(18.5-25 \mathrm{~kg} / \mathrm{m}^{2}\right)$ and a high BMI $\left(>25 \mathrm{~kg} / \mathrm{m}^{2}\right)$. The average PAL was, respectively, $1.84 \pm 0.27,1.87 \pm 0.26$ and $1.86 \pm$ 0.26 , which was not significantly different between the groups [10].

Physical activity questionnaires and physical activity diaries are a more subjective method than the doubly labeled water method and people have often a tendency to overestimate their physical activity. Conway et al compared energy expenditure estimates from doubly labeled water, a physical activity questionnaire and physical activity records. The physical activity level measured with the questionnaire and with the activity record was, respectively, $30.6 \pm 9.9 \%$ and $7.9 \pm 3.2 \%$ higher than the doubly labeled water assessed physical activity [11]. However, activity questionnaires can reach large populations and therefore we considered them as well in this paragraph on physical activity.

Schaller et al used in their study, performed in 2004, three computer-based 24-hour telephone recalls. They assessed type and duration of physical activity in the domains occupation, sports, other strenuous leisure time activities of mostly moderate intensity, as well as television and computer use in leisure time and duration of sleeping, in 893 participants living in Bavaria, Germany. Only $26.8 \%$ of women and $36.4 \%$ of men had a calculated PAL of 1.75 or higher, as recommended by the
WHO. These numbers were lower with increasing age and BMI [12]. A large study on physical inactivity, sedentary lifestyle and obesity in the European Union measured in 15,239 men and women (older than 15 years) physical activity using standardized in-home questionnaires administered by professional interviewers. The weekly hours of sitting down were positively related to the prevalence for obesity (BMI $>30 \mathrm{~kg} / \mathrm{m}^{2}$ ) and the leisure time physical activity was negatively related to the prevalence for obesity. Whether this was a cause or a consequence is not known as this was a cross-sectional study [13].

The Minnesota Heart Survey showed trends in cardiovascular risk factors in 4000-6000 adults (25-74 y) living in Minnesota from 1980-82 to 1985-87 and to 1995-97, including physical activity [14]. Physical activity was assessed with questionnaires. Leisure time physical activity remained rather stable over the years for both men and women. The proportion of the population who didn't regularly engage in physical activity increased with about $5 \%$ over these 15 years. Steffen et al analyzed the same data and concluded that daily energy expenditure from lifestyle physical activity and leisure time physical activity both increased between 1980 and 2000 while workplace activity was decreased [15].

Large studies using objective physical activity assessment methods are necessary to get a clear picture of the physical activity in different countries and populations. Accelerometers are physical activity assessment methods, which could be used in such large trials to get an objective picture of the PAL, the $\mathrm{AEE} / \mathrm{kg}$ body mass and $/$ or the time engaged in low, moderate and high intensity activities. Knowledge on the intensity of the physical activity, in addition to measured energy expenditure with the doubly labeled water method, can provide information on the post exercise energy expenditure. Vigorous physical activity increases post-exercise energy expenditure and attenuates even post-exercise energy intake compensation [16].

Westerterp reviewed three field methods for the assessment of physical activity and concluded that an accelerometer is a more objective tool than activity questionnaires or than heart rate monitoring [17]. These accelerometers should preferably been validated against doubly labeled water method to get reliable figures on energy expenditure and physical activity levels. Furthermore, accelerometers can also be used to measure activity patterns and activity intensity [18].

In conclusion, doubly labeled water measurements showed that roughly half of the measured population had a physical

Table 2

Mean physical activity level, doubly labeled water assessed total daily energy expenditure as a multiple of resting energy expenditure, by gender, age, and body weight group [9]

\begin{tabular}{|c|c|c|c|c|}
\hline \multirow[b]{3}{*}{ Age (y) } & \multicolumn{2}{|l|}{ men } & \multicolumn{2}{|l|}{ women } \\
\hline & normal & overweight & normal & overweight \\
\hline & weight & or obese & weight & or obese \\
\hline $19-30$ & 1.74 & 1.85 & 1.80 & 1.77 \\
\hline $31-50$ & 1.81 & 1.85 & 1.83 & 1.79 \\
\hline $51-70$ & 1.63 & 1.72 & 1.70 & 1.59 \\
\hline
\end{tabular}


activity level comparable to what is recommended by the WHO. Furthermore no difference was found between normal or overweight people. A large trial in the European Union showed a negative relation of body mass index with leisure time activity and a positive relation with hours per week spent sitting. The Minnesota Heart Survey showed an increase in the number of inactive people over time. Thus, we conclude that physical inactivity cannot be the major or only cause for the increasing prevalence of obesity.

\subsection{Energy intake}

Energy intake measurements in man are generally based on self-reported food intake. Thus, reliable population levels of energy intakes are very hard to get. People might forget to report the foods they have consumed, change their diet while recording their food or they might report to expected rather than their real food intake. All current available dietary assessment methods suffer from one or more of the problems mentioned above [19]. Despite these problems large national food consumption studies have been carried out to get information on national food consumption trends.

National food consumption studies within the USA (NHANES studies) showed a reported energy intake at the population level of $8.3 \mathrm{MJ} /$ day in 1972, 8.3 MJ/day in 1978, 9.2 MJ/day in 1990, and $9.0 \mathrm{MJ} /$ day in 2000. Briefel et al. [20] calculated for the data of NHANES III (1990) that an intake of $9.2 \mathrm{MJ} /$ day means on average a ratio of reported energy intake (EI) to estimated basal metabolic rate (BMR) of 1.36. For a sedentary population one would expect a ratio between 1.50 and 1.55 as the ratio EI/BMR should equal energy expenditure (EE)/ BMR on population level. This indicates an underreporting of energy intake, which considering the lower reported energy intakes, was even a larger problem for NHANES I and II $[20,21]$.

National food consumption studies performed in the Netherlands showed somewhat higher reported energy intake as reported within the NHANES food consumption studies [22]. However also in these studies one cannot exclude dietary underreporting.

Food intake data derived from food balance sheets as used as an indication on national food consumption trends. Balanza et al. [23] performed an ecological study on the basis of Food and Agriculture Organization food balance sheets for three areas in Europe, namely Mediterranean, North and East Europe. The food availability data showed a considerably increase in total energy availability and energy from lipids over the last 40 years. On the other hand a fall of $20.5 \%$ from carbohydrate consumption was found. Within the WHO Monica project from the early 1980s to the mid-1990s annually reported country food data were related to body mass index in 34 adult populations in 21 countries. The differences in trends of total energy supply per capita between countries explained $41 \%$ of the variation of trends in mean BMI [24].

In conclusion, while national food consumption studies cannot give us the answer whether we eat now more than years ago, food balance sheet data do suggest so.

\subsection{Dietary fat intake}

Underreporting of food intake might implicate selectively underreporting of fat intake. In a study of Goris et al. in 30 obese men, energy expenditure was measured with the doubly labeled water method and food intake was measured with a 7 day food record. Total food intake was underreported with $37 \pm 16 \%$ and the reported percentage of energy from fat was a function of the level of underreporting $\left(\mathrm{R}^{2}=0.28, \mathrm{P}<0.01\right)$. Mean reported energy percentage from fat was $39 \pm 6 \%$, and, in the case of no underreporting, the percentage of energy from fat would be $46 \pm$ $5 \%$ [25]. This study was done using a 7 day dietary record, but also in studies using food frequency questionnaires selective underreporting of fat intake has been found. Fig. 1 shows reported dietary fat intake for the USA (NHANES studies) and the Netherlands from, respectively, 1972 and 1987 until 2003. For both populations, a clear negative trend is visible. However, the question is whether this is a real trend or is a reflection of
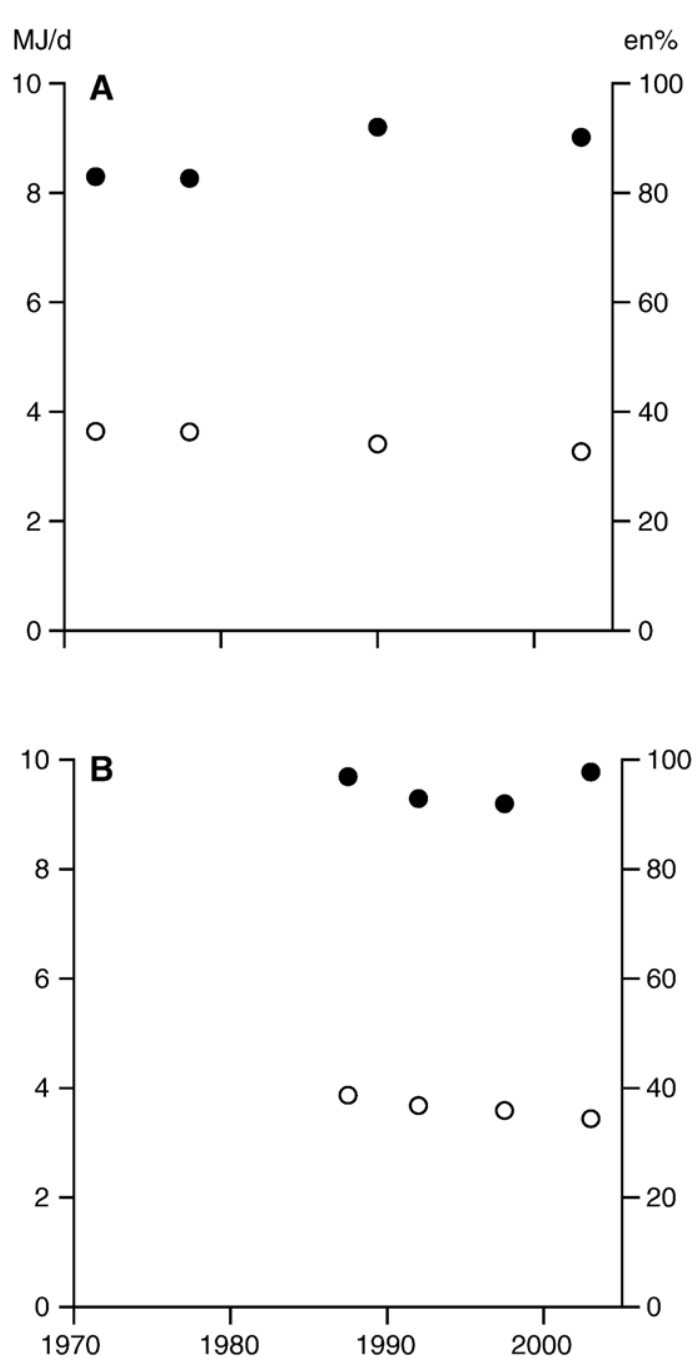

Fig. 1. A: Reported energy intakes (symbols, right axis, $\mathrm{kJ} /$ day) and dietary fat (bars, left axis, \% energy) for the USA $[21,26]$. B: Reported energy intakes (symbols, right axis, $\mathrm{kJ} /$ day) and dietary fat (bars, left axis, \% energy) for the Netherlands [22]. 
reporting according to health campaigns aimed at lowering fat intake while the real dietary fat intake remained unchanged.

Ernst et al compared reported (saturated) fat intakes of the NHANES studies with measured serum cholesterol levels [26]. They compared the observed changes in serum cholesterol levels with the classic Keys and Hegsted formulas and found that the reduced serum cholesterol level could be predicted by the changes in dietary (saturated) fat intake. However there are still many other factors that affect the serum cholesterol levels of individuals and only at population level reported fat intakes were compared to changes in serum cholesterol levels. Food supply data of the US population showed that the major change is in type of fat intake rather than total fat intake over the years. Food supply data reviewed by Balanza et al within Europe showed an increase in dietary fat intake over the past 40 years [23]. Thus, a clear reduction of dietary fat intake is not proven yet and there are indications for the opposite, giving a potential explanation for the current obesity epidemic.

\subsection{Dietary fat and body fat}

A shift in the diet to a higher contribution of fat leads to an increase in body weight [27]. Due to a high palatability, a relatively high energy density, and a weak effect on satiation, the consumption of high-fat foods induces passive overfeeding [28]. Thus, dietary fat is amongst the most important factors for the development of obesity [29]. An intervention study, where subjects were randomly assigned to either a group consuming reduced-fat products or a group consuming full-fat products for six months, showed that the fat content has an effect on body fat as a function of the effect of dietary fat on energy intake [30].

Fat, as a substrate for energy metabolism, is at the bottom of the oxidative hierarchy that determines fuel selection [31]. We recently showed that dietary fat oxidation, as measured over 12 hours after a breakfast containing deuterated palmitic acid, was negatively related to body fatness, where lean subjects showed the highest and obese subjects the lowest values [32]. All subjects were observed under similar sedentary conditions in a respiration chamber, without activity equipment or an imposed activity protocol.

Physical activity increases fat oxidation [33]. Moderateintensity exercise yields the most grams of fat used for oxidation in the average individual [34], inactivity reduces the oxidation of saturated but not monounsaturated dietary fat [35], and exercise increases monounsaturated fat oxidation more than saturated fat oxidation regardless of exercise intensity [36]. A combination of a high-fat intake and physical inactivity has a higher risk for obesity than a combination of a high-carbohydrate diet and physical inactivity [37]. Thus, regular physical activity is protective and helps to maintain a healthy body composition [38]. It reduces the time to match fat intake to a change in the percentage fat in the diet.

Under particular circumstances as in the case of post-obese individuals having been subjected to a surgery exercise may exceptionally attenuate fat loss. A study of Westerterp and Tremblay showed a strong relationship between mean daily RQ and PAL (RQ=0.549 PAL $+0.051, r=0.96)$ in these post-obese individuals, indicating that an increase in activity participation was associated with an increase in the relative carbohydrate content of the daily substrate mix and a decrease in the percentage of lipid oxidized. It was suggested that exercise attenuated the reducing effect of surgery on body fat stores because RQ, which was already at its minimal level (0.70) 6 weeks after surgery, was increased rather than decreased by physical activity participation $[39,40]$.

\section{Summary}

Contrary to the suggestion of Prentice and Jebb [41], that modern inactive lifestyles are at least as important as diet in the etiology of obesity and possibly represent the dominant factor, excessive energy intake is a more plausible explanation. Man is a discontinuous eater and a continuous metaboliser. A typical human eats three to four times a day to cover total daily energy expenditure. Thus, daily energy intake takes 30 to $60 \mathrm{~min}$ for 24-hour energy expenditure, a behavior selected for during evolution in an environment with a high predation pressure. Nowadays, food is often readily available and can be consumed in a safe environment. Then, the normal eating rate at four to five times the expenditure rate during high intensity exercise results in a high risk for overeating.

Dietary trends in the 'battle' against obesity were, respectively, low fat, low carbohydrate and high protein. Whatever diet is consumed, it is not the diet composition but total energy intake that counts. Every 'diet rule' restricts the diet choice with a potential limitating effect on energy intake. Additional effects are, amongst others, through energy density and diet-induced thermogenesis [42].

A reduction in dietary fat without intentional restriction of energy intake causes weight loss, especially in heavier subjects, as shown in a meta-analysis of ad libitum dietary intervention studies [43]. Here, the fat content has an effect on body fat as a function of the effect of dietary fat on energy intake [30]. The apparent success of low carbohydrate foods in the prevention of overweight can be linked to a reduction of food intake by the deliberate limitation of food choice and by a higher thermogenesis-induced satiety when the reduction of carbohydrate intake results in an increase in protein intake [42].

In conclusion, there is no convincing evidence for a change of physical activity over the last decades while food intake, especially dietary fat intake, remained high. Short-term exposures to an increased dietary fat intake should be accompanied by physical activity to prevent body fat accumulation in time.

\section{References}

[1] James PT, Leach R, Kalamara E, Shayeghi M. The worldwide obesity epidemic. Obes Res 2001;9:228S-33S.

[2] Wang Y, Beydoun MA. The obesity epidemic in the United States gender, age, socioeconomic, racial/thnic, and geographic characteristics: A systematic review and meta-regression analysis. Epidemiol Rev May 2007;17 (Electronic publication ahead of print).

[3] Willet WC, Dietz WH, Colditz GA. Guidelines for healthy weight. NEJM 1999;341:427-34. 
[4] Ezzati M, Lopez AD, Rodgers A, Vander Hoorn S, Murray CJL, and the Comparative Risk Assessment Collaborating Group. Selected major risk factors and global and regional burden of disease. Lancet 2002;360:1347-60.

[5] Hoos MB, Westerterp KR, Kester ADM, Gerver WJ. Physical activity levels in children and adolescents. Int J Obes 2003;27:605-9.

[6] Ekelund U, Yngve A, Brage S, Westerterp K, Sjöström M. Body movement and physical activity related energy expenditure in children and adolescents: How to adjust for differences in body size and age. Am J Clin Nutr 2004;79:851-6.

[7] Brooks GA, Butte NF, Rand WM, Flatt JP, Caballero B. Chronicle of the institute of Medicine physical activity recommendation: how a physical activity recommendation came to be among dietary recommendations. Am J Clin Nutr 2004;79:21S-930S.

[8] Saris WHM, Blair SN, Van Baak MA, Eaton SB, Davies PS, Di Pietro L, et al. How much physical activity is enough to prevent unhealthy weight gain? Outcome of the IASO 1st Stock Conference and consensus statement. Obes Rev 2003;4:101-14.

[9] Blair SN, LaMonte MJ, Nichaman MZ. The evolution of physical activity recommendations: how much is enough. Am J Clin Nutr 2004;79:13S-920S.

[10] Butte NF, Treuth MS, Metha NR, Wong WW, Hopkinson JM, O'Brian Smith E. Energy requirements of women of reproductive age. Am J Clin Nutr 2003;77:630-8.

[11] Conway JM, Seale JL, Jacobs DR, Irwin ML, Ainsworth BE. Comparison of energy expenditure estimates from doubly labeled water, a physical activity questionnaire, and physical activity records. Am J Clin Nutr 2002;75:519-25.

[12] Schaller N, Seiler H, Himmerich S, Karg G, Gedrich K, Wolfram G, et al. Estimated physical activity in Bavaria, Germany, and its implications for obesity risk: results from the BVS-II Study. Int J Behav Nutr Phys Act 2005;8:2:6.

[13] Martínez-González MA, Martínez JA, Hu FB, Gibney MJ, Kearney J. Physical inactivity, sedentary lifestyle and obesity in the European Union. Int J Obes Relat Metab Disord 1999;23:1192-201.

[14] Arnett DK, McGovern PG, Jacobs DR, Shahar E, Duval S, Blackburn H, et al. Fifteen-year trends in cardiovascular risk factors (19080-1982 through 19951997) The Minnesota Heart Survey. Am J Epidem 2002;156:29-935.

[15] Steffen LM, Arnett DK, Blackburn H, Shah G, Armstrong C, Luepker RV, et al. Population trends in leisure-time physical activity: Minnesota Heart Survey, 1980-2000. Med Sci Sports Exerc 2006;38:1716-23.

[16] Tremblay A, Doucet E. Influence of intense physical activity on energy balance and body fatness. Proc Nutr Soc 1999;58:99-105.

[17] Westerterp KR. Assessment of physical activity level in relation to obesity: current evidence and research issues. Med Sci Sports Exerc 1999;31: S522-5.

[18] Westerterp KR. Impacts of vigorous and non-vigorous activity on daily energy expenditure. Proc Nutr Soc 2003;62:645-50.

[19] Westerterp KR, Goris AH. Validity of the assessment of dietary intake: problems of misreporting. Curr Opin Clin Nutr Metab Care 2002;5: 489-93.

[20] Briefel RR, McDowell MA, Alaimo K, Caughman CR. Total energy intake of the US population: the third National Health and Nutrition Examination Survey, 1988-1991. Am J Clin Nutr 1995;62:1072S-80S.

[21] CDC/NCHS. NHANES IV (1999-2000), 334. Advanced Data, Vital and Health Statistics; April 172003.

[22] Bijman J, Pronk B, Graaff R. de. Wie voedt Nederland. Consumenten en aanbieders van voedingsmiddelen. Den Haag LEI; 2003.

[23] Balanza R, Garcaa-Lorda P, Paorez-Rodrigo C, Aranceta J, Bonet MB, Salas-Salvada J. Trends in food availability determined by the Food and Agriculture Organization's food balance sheets in Mediterranean Europe in comparison with other European areas. Public Health Nutr 2007;10: $168-76$.

[24] Silventoinen K, Sans S, Tolonen H, Monterde D, Kuulasmaa K, Kesteloot $\mathrm{H}$, et al. WHO MONICA Project. Trends in obesity and energy supply in the WHO MONICA Project. Int J Obes Relat Metab Disord 2004;28: $710-8$.

[25] Goris AH, Westerterp-Plantenga MS, Westerterp KR. Undereating and underrecording of habitual food intake in obese men: selective underreporting of fat intake. Am J Clin Nutr 2000;71:130-4.

[26] Ernst ND, Sempos CT, Briefel RR, Clark MB. Consistency between US dietary fat intake and serum total cholesterol concentrations: the National Health and Nutrition Examination Surveys. Am J Clin Nutr 1997;66: 965S-72S

[27] Lissner L, Levitsky DA, Strupp BJ, Kalkwarf HJ, Roe DA. Dietary fat and the regulation of energy intake in human subjects. Am J Clin Nutr 1987;46: 886-92.

[28] Westerterp KR. Perception, passive overfeeding and energy metabolism. Physiol Beh 2006;89:62-5.

[29] Bray GA, Paeratakul S, Popkin BM. Dietary fat and obesity: a review of animal, clinical and epidemiological studies. Physiol Beh 2004;83: 549-55.

[30] Westerterp KR, Verboeket-van de Venne WPHG, Westerterp-Plantenga MS, Velthuis-te Wierik EJM, De Graaf C, Weststrate JA. Dietary fat and body fat: an intervention study. Int J Obes 1996;20:1022.

[31] Prentice AM. Manipulation of dietary fat and energy density and subsequent effects on substrate flux and food intake. Am J Clin Nutr 1998;67 (3Suppl):S535-41.

[32] Westerterp KR, Smeets A, Lejeune MP, Wouters-Adriaens MPE, WesterterpPlantenga MS. Dietary fat oxidation as a function of body fat. Am J Clin Nutr (in press).

[33] Schrauwen P, Westerterp KR. The role of high-fat diets and physical activity in the regulation of body weight. Br J Nutr 2000;84:417-27.

[34] Hansen K, Shriver T, Schoeller D. The effects of exercise on the storage and oxidation of dietary fat. Sports Med 2005;35:163-73.

[35] Bergouignan A, Schoeller DA, Normand S, Gauquelin-Koch G, Laville M, Shriver T, et al. Effect of physical inactivity on the oxidation of saturated and monounsaturated dietary fatty acids: results of a randomized trial. PLoS Clin Trials 2006;1:e27.

[36] Votruba SB, Atkinson RL, Schoeller DA. Prior exercise increases dietary oleate but not palmitate oxidation. Obes Res 2003;11:1509-18.

[37] Shepard TY, Weil KM, Sharp TA, Grunwald GK, Bell ML, Hill JO, et al. Occasional physical inactivity combined with a high-fat diet may be important in the development and maintenance of obesity in human subjects. Am J Clin Nutr 2001;73:703-8.

[38] Hansen KC, Zhang Z, Gomez T, Adams AK, Schoeller DA. Exercise increases the proportion of fat utilization during short-term consumption of a high-fat diet. Am J Clin Nutr 2007;85:109-16.

[39] Westerterp KR, Tremblay A. Exercise and energy balance following obesity surgery. Int J Obes 1995;19(Suppl 4):S131.

[40] Westerterp KR, Saris WH, Soeters PB, ten Hoor F. Determinants of weight loss after vertical banded gastroplasty. Int J Obes 1991;15:529-34.

[41] Prentice AM, Jebb SA. Obesity in Britain: gluttony or sloth? Br Med J 1995;311:437-9.

[42] Westerterp-Plantenga MS, Luscombe-Marsh N, Lejeune MP, Diepvens K, Nieuwenhuizen A, Engelen MP, et al. Dietary protein, metabolism, and bodyweight regulation: dose-response effects. Int J Obes 2006;30(Suppl 3): S16-23.

[43] Astrup A, Grunwald GK, Melanson EK, Saris WHM, Hill JO. The role of low-fat diets in body weight control: a meta-analysis of ad libitum dietary intervention studies. Int J Obes 2000;24:1545-52. 